\title{
Javanese Leadership Encountering Global Culture
}

\author{
Prof. Pawito, Ph.D \\ Communication Department, Faculty of Social and Political Sciences, Sebelas Maret University. \\ pawito_palimin@staff.uns.ac.id
}

\begin{abstract}
Keywords: local wisdom, leadership style, javanese traditional leadership, global culture.
Abstract: $\quad$ The study deals with Javanese traditional leadership. As global culture penetrates nearly all aspects of social life including leadership, it could be stipulated that the cultural values of Javanese traditional leadership need to be negotiated with global values of leadership especially those derived from western scientific thinking and/or practices of leadership. The study thus attempts to scrutinize the ways in which Javanese traditional leadership has been negotiated. By using primarily Bass transformational leadership style to provide understanding of leadership practices in a more contemporary perspective, the study suggests that the negotiation involves three foremost ways namely (a) by adopting foreign values of leadership, (b) developing new hybrid values, and (c) maintaining genuine values of leadership albeit in new performance.
\end{abstract}

\section{INTRODUCTION}

The term leadership could be understood in varieties of way. Senge (1990), for an example, suggests that leadership is " .... the process of persuasion or example by which an individual or team induces a group to act."

It seems that Senge in this respect emphasizes the notions of persuasion process and inducement pursuing for mutual act between a leader and his or her followers. This means that communication skill is a prominent factor for effective leadership. In any persuasion process it is essentially needed that communicator (the leader) and communicant share messages and/or information seeking for mutual understanding and, moreover, mutual action.

Bennis and Townsend (1995), parallel with Senge, confirm that that leadership is "the capacity to create a compelling vision and to translate vision into organizational realities" There are two major notions which Benis and Townsend have emphasized namely (a) the capacity to create a compelling vision, and (b) to translate vision into organizational realities. Again, communication is also necessarily needed in both of the two notions already mentioned. How a leader can create and compelling vision and how a leader can translate vision into organizational realities, it could be argued, have their basic requirement of communication. Thus if leaderships are seen as a process, then the process of persuasion, the inducing process, creating compelling visions and translating vision into organizational realities are simply communication process. It could be hard therefore to think leadership without taking into account of communication. In nowadays perspective, as Silva (2016) remarks, a definition of leadership that might be considered more satisfactory is "the process of interactive influence that occurs when, in a given context, some people accept someone as their leader to achieve common goals."

One of foremost critical points regarding leadership, it could be emphasized, is how a leader to persuade and induce other people, to encourage other people achieving common goals, to formulate and then translate his or her vision into reality. The questions already arise might be followed by other questions albeit without any adequate answers. Indeed these questions deal with method or style of leadership that could also be found in variety of ways. It seems that a number factors such as culture, environment, and situation influence leadership style implemented by leaders. To put in another way, different places, situations and culture requires unique implementation of leadership style. This could be the case in anywhere around the globe including in Indonesia in which Javanese-born leaders play 
significant roles such as in governmental and/or political context, business and other fields.

As nowadays global culture has been becoming an unavoidable phenomenon and penetrating wide spectrum of life, it is important therefore to examine Javanese leadership style by putting it into a perspective of global culture penetration. This study hence attempts to seek understandings dealing this issue.

\section{METHODS}

This research used historical qualitative method because the focus of the research is connecting local wisdom with global culture. As we know that so many local wisdom formed from history which usually has a long history. Main data and information collected through literature and observation. Historical qualitative methods enables to excavate literature and observations more detail.

\section{RESULT AND DISCUSSION}

\subsection{Global Culture and Leadership Style}

Global culture, to put in a short way, is culture which have characteristic nuance of transcendent national boarder and also could easily be found in around the globe. The cultural values of global culture are thus to be shared among the Earth's inhabitants and often have similar standards (Rettig, 2017; Dubberke, 2012; Spacey, 2018). Fashion, sports, language, food, belief, education, business and leadership style, among others, are some examples of the manifestation of global culture. Communication technologies such as the Internet, social media, mass media and other electronic communication devices contribute significantly in creating and developing global culture. The spread of global culture, it could be stipulated, has very wide impacts on the life of society in all around the world including leadership.

For many respects global culture has been altering leadership thinking as well as practices so that leadership styles have been changing over time. Leadership styles in the industrial are extremely different to those of post-industrial era. As Rost insisted leadership style in industrial era has dominant character of, to put in Rost's words: "certain preferred traits influencing followers to do what the leaders wish in order to achieve group/organizational goals that reflect excellence defined as some kind of higher-order effectiveness (Rost, 1993: 180. It could be emphasized in this respect that the wish of the leaders is very the prominent character. Despite the fact that, to some extent at least, this character of leadership can easily be found in many organizations and/or corporations in Indonesian context, it seems that the implementation of the such like leadership style has the consequence of failing in pursuing at optimum advantageous outcome dealing primarily with organization and/or corporation goals.

Radically different, leadership in the postindustrial era as Rost maintained, has the major principles of relation-based between the leader and the followers and have a high regard for noncoercive interaction and/or communication for the sake of mutual achievement as well as common interest. Leadership in the era of post-industrial society (often called information society) could be defined as, to put in Rost' words, “... an influence relationship among leaders and followers who intend real change that reflect their mutual purposes." (Rost, 1993:180). In this respect Rost emphasized mutual purposes between leaders and followers based on influence. Yet a number of critical points could be a real evidence regarding mutual purposes; and for Rost the critical points include (a) influence is the basic element of relationship between leaders and followers, (b) both leaders and followers are participants in this relationship hence both of the two may share common ideas, (c) mutual purposes has to be developed on the basis of mutual understanding between leaders and followers, and (d) significant changes in a sense of achievement progress are the major intend of both leaders and followers.

To many extent, it could be stipulated, global culture dominated by western culture, including leadership, has been influencing on leadership practices in nearly all around the world including in nowadays Indonesia even though the term of global culture may imply an endless process of interaction among different cultures around the globe. This impact seems occur in many fields (and/or level) in Indonesian context including those with respect to politics, social life, economy, and education. Consequently, many styles of leadership derived from western culture have been adopted in nowadays Indonesia including in business organizations, government 
organizations and many other kinds of organizations and/or associations. As the leaders of the organizations and/or associations are, among others, Javanese so negotiations between Javanese cultural values and the global cultural values of leadership have been real cases. It seems very essential that Indonesian Javanese-born leaders need to negotiate genuine Javanese traditional value of leadership with global values of leadership originated primarily from western culture.

\subsection{The Change of Need Fulfillment in Consumption Rationality among Smartphone Users}

\subsubsection{Adopting Global Values}

It seems not easy to identify the ways in which Javenese traditional leadership styles has been negotiated with those from global culture. However, despite the complexity of the process of negotiations it could be argued that the negotiations may go in three possible ways namely (a) to adopt foreign values of leadership pursuing at optimum achievements for the sake of the goals of the organization to be attained, (b) developing new hybrid values, and (c) maintaining genuine values of leadership albeit by adopting new nuances. To some extents, however, the three ways of negotiation are not significantly mutual exclusive; rather the three ways often intersect with each other. Scrutinizing a number of contemporary leadership practices by Indonesian Javanese-born it could be emphasized that the three ways of negotiation share some basic values to some extent at least.

In adopting foreign values especially in term of encouraging followers to seize the future in a more confident way Susilo Bambang Yudhoyono (SBY), for an example, used the jargon of "Yes We Can." It is very clear that the jargon had been used by Barack Obama before especially during his long campaign as well as during his presidency both in the first period and the second period as well (2009-2017). Put this jargon over and over again SBY spoke in Bahasa Indonesia: "Bersama Kita Bisa" instead of "Ya Kita Bisa." Having an emphasize of "bersama", it could be understood that Yudhoyono had been demanding togetherness - leadership style by maximum involvement of the people from all around of the country.
A bit long before, primarily during early period of his office (1972-1983) Soeharto appointed to be the ministry of the government numerous persons from foremost university mostly graduated from the US including for example Prof. Dr. Emil Salim, Prof. Dr. Widjojo Nitisastro, Prof. Dr. Subroto, Prof. Dr. Franz Seda and others. This could be meant that the distribution of power and/or trust was set up on the basis of merit to the people who very capable in the filed so that the appointment had based on merit instead of merely on personal relations. In most traditional leadership practices, it could be emphasized, power is shared on the basis of personal relations (family, clan) - meaning that power distributions are arranged mostly by considering personal relations. Therefore the ministry that had being set during the period above mentioned could be said as a big jump namely adopting new leadership values derived from global values pursuing for most advantageous achievements.

The such like policy already mentioned seems to be an essential requirement of leadership practices in nowadays modern including, indeed in Indonesian context. As Prewitt, Weil and MacClure (2011) remark, "with ever increasing globalization and change, leaders will be challenged to manage relationships more than in the past. This will include the ability to interact effectively with diversity of partners and other businesses and within the larger context of differing cultures."

\subsubsection{Developing new hybrid values}

It seems that developing new hybrid values is the most usual way employed by Indonesian Javanese-born leader. In many occasions Javanese-born leaders bring into being elements of Javanese traditional leadership to appeal or to motivate followers to be more enthusiastic in attaining the goal. Yet in this respect Javaneseborn leaders typically implement this way in sensible formulas. When Soeharto spoke about tut wuri handayani (literally means better readily to backup), for example, this notion is derived from the Taman Siswa's ethic of leadership proposed by Ki Hajar Dewantoro (a Javanese philosopher and educator) which consists of three major pillars: (a) Ing ngarso sung tulada (providing exemplars when taking and/or being set in front line or higher rank of position), (b) Ing madyo mangun karso (could keenly provide motivation 
or encouragement to others when taking and/or being set in middle rank of position), and (c) Tut wuri handayani.

It could be said that this Javanese leadership style shares the elements of transformational leadership proposed by Bass. Bass (1985) in this respect suggested a new leadership style namely transformational leadership based on Burn's notion of transforming leadership. By transforming leadership Burn (1978) put an emphasis on mutual engagement between a leader and his or her followers pursuing at common goals. Bass subsequently built a new style of leadership namely transformational leadership based on Burn's transforming leadership. With the notion of transformational leadership Bass underlined the three major pilars of (a) the capacity of encouraging and/or empowering followers to be aware of their task outcome, (b) the capacity of hastening followers in surpassing personal interest pursuing at the goals both in term of team and organization as well, and (c) the capacity of elevating followers motivation to reach higher level of achievement.

Another example, when Soeharto spoke in 1980-s at the opening ceremony of the big dam Gajah Mungkur Wonogiri Central Java Soeharto remarked that any people should recognize the imperious category of necessesity to sustain the dam. Appealing the people Soeharto insisted that the people "Wajib Melu Handarbeni" (it is compulsory for any people to think that the dam is obviously yours). The philosopical idea of wajib melu handarbani is originated from Sri Mangkunegara IV's Wulangreh which includes the three pillars of (a) Wajib melu handarbeni (sense of belonging), (b) Melu hangrungkebi (it is compulsory that everyone has to participate in maintaining development achievements), and (c) Mulat sariro hangroso wani (being self understanding of what should be do) for others and/or the nation. This three notions of Javanese culture which Soeharto had used pursuing at people belief as well as participation to development programs. Yet it could be emphasized that all of the three pillars already mentioned have been very relevant to nowadays leadership practices in Indonesian context especially for encouraging and/or motivating people pursuing at people belief as well as participation to reach the goal of organizations and/or corporations. Moreover, despite the fact that providing encouragement and motivation to followers are major element of global culture regarding particularly leadership practice, Javanese traditional leadership values are found convergence with those of global cultural values.

\subsection{Maintaining Genuine Values}

It has been the case that maintaining genuine values often be implemented by Indonesian Javanese-born leaders. In this respect, despite the facts that this has been carried out in new piece, Javanese leaders tend to give the impression of countering global culture. In the early of Pelita II (1 April 1973 - 31 March 1978) Soeharto adopted the policy of economy development by emphasizing agriculture sector in conjunction with industrial sector in term primarily to proceed raw material into basic component including for food industry, textile, rubber and steel. During this period Soeharto had been traveling to many parts of the country pursuing for closer relationships to the people. The policy subsequently was being continued in Pelita III ( (1978 - 1983) and was able to achieve what usually called "Swasembada Beras" by 1984 . Benefiting from 9.8 ha rice field with the involvement of 12 millions of farmers the production of rice had reached to 25.8 millions ton. (Arumdanie, 2002: 1108-9).

It could be argued that trips by trips that Soeharto had carried out pursuing for having close relationship to the people particularly during 1973-1988 were very notable of ways to appeal the people and to seek massive participations of people in whatever development programs of the government. This could be understood by putting it into Hastobroto along with Tamansiswa Javanese traditional leadership style that already mentioned. Hastobroto leadership style comprizes an-eight elements which are significantly characterized by harmonious relationship beetween macro-cosmos (the universe) and micro-cosmos (the individual person of the leader) (see Appendix). The elemens of watak suryo, watak condro and watak maruto provide clear references in understanding leadership style employed by Soeharto during his period time of power.

However, when Soeharto had to stand facing the element of opposition such as Petisi 50, just for an example, Soeharto was found adopting more coercive policy and subsequently a bit of edgy political situation came to be the case. It seems that in this respect Soeharto adopted the element of watak geni (the character of fire) 
attempting at providing a total solution for any serious problems.

Joko Widodo (Jokowi) is another Javaneseborn Indonesian leader. Born in very long after The War, grew without any military background and spent his life mostly in business activities, Jokowi has been adopting a unique mixture of leadership style. One of the prominent angagement that Jokowi undertook is what the so called blusukan. Despite often be criticized as merely seeking for good images, it could be argued, that undertaking trips to make close relationship to the people is a major technique of Javanese traditional culture of leadership. That is why most Indonesian Javanese-born leaders keenly arrange this approach including Soeharto, Yudhoyono and Jokowi as well.

It could be stipulated that pursuing for close relationship between leaders and the people by undertaking trips to meet the people, to attempt at understanding the conditions as well as the demands of the people has rooted to long period of ancient time namely Mataram Kingdom iconed by Panembahan Senopati. Senopati's style of leadership provided an exemplar of Javanese traditional leadership which subsequently was being formulated by Ki Ageng Soerjo Mentaram (a Javanese philosopher) and identified as Hasto Broto leadership style. Oftenly being pleased about a macapat sinom (traditional Javanese song) some elements of the leadership style could be mentioned, part of them, as follows :

"Samangsane pasamuwan

Mamangun marta martani

Sinambi ing saben mangsa

Kala-kalaning asepi

Lelana teki-teki

Nggayuh geyonganing kayun

Kayungyun eninging tyas

Sanityasa pinrihatin

Punggung-panggah cegah dahar lawan nendra."

\section{CONCLUSION}

Coming to an ending remark it is fair to stipulate that culture as well as environment, among other factors, influence the implementation of leadership style significantly in term primarily of practices. Soeharto, take it for an example, is an Indonesian Javanese-born leader who had spent his young period of life mostly in the era of war i.e The Second World War and then joined into Indonesian army and intensively involved in struggling for national independent. Thus the leadership style that he had been employed has the character nuance of Javanese culture (mostly because he is simply a Javanese) which was being negotiated with global culture so that was significantly marked with pursuing harmony relationship between the leader and the people albeit the nuance of coercive (one of major element of post-war leadership) was often be the case. The last point already mentioned is one of the consequences, among others, of the military background and the involvement of many sequences of combating for national independent. As Soeharto had adopted global values of leadership especially in the early period of his ascendancy then it should be emphasized that Soeharto's leadership style provides an exemplar of negotiation namely adopting global values to some extent and, at the same time, maintaining genuine Javanese culture values of leadership including Hastobroto, Tamansiswa and Bocah Angon leadership style.

It is important to emphasize that, as UNESCO seems to appeal, "balancing the benefits of integrating into a globalized world against protecting the uniqueness of local culture requires a careful approach. Placing culture at the heart of development policies does not mean to confine and fix it in a conservative way, but on the contrary to invest in the potential of local resources, knowledge, skills and materials to foster creativity and sustainable progress." (http://www.unesco.org/new/en/culture/themes/c ulture-and-development/). The above remark might provide a more fair and comprehensive understanding of Javenese leadership in nowadays Indonesia especially in the context of global culture penetration.

\section{REFERENCES}

Arumdanie, Koos, "Ketahanan Pangan Dalam Pembangunan" in Koos Arumdanie (ed.) 2002. Pak Harto anak Desa Membangun Kepentingan Nasional. Jakarta:UMB Press.

Bennis, W.G. and Townsend, R. 1995. Reinventing leadership, New York: Collins Business Essential.

Burns, James MacGregor. 2003. Transforming Leadership: A new pursuit of happiness. 
New York, NY: Antlantic Montly

Presmaintaines.

Dubberke, Sean, 2012, "Is A 'Global Culture'

Possible?"

(https://www.rw-3.com/blog/2012/11/is

....)

FME Team. 2015. Leadership Theories Leadership

Skill. www.free-management-ebooks.com.

Northouse, Peter G. 2013. Leadership: Theory and

Practice. Thousan Oaks, CA.: Sage

Publication Inc.

Prewitt, James, Richard Weil and Anthony McClure, "Developing Leadership in Global and Multi-cultural Organizations", International Journal of Business and Social Science, Vol. 2 No. 13 - Special Issue - July 2011.

Rettig, Tim, 2017, "What Is Global Culture? What are some examples?"

(https://www.quora.com/What-is-globalculture-...)

Rost, Joseph C. 1993. Leadership For The TwentyFirst Century. West Port, CT : Praeger Publisher.

Senge, P.M. 1990. The Fifth Discipline: The Art and Practice of the Learning Organization. New York, NY.: Currency Doubleday.

Silva, Alberto, "What is Leadership", Journal of Bussiness Studies Quarterly, 2016 Volume 8, Number 1.

Spacey, John, 2018. "17 Examples of Global Culture". (https://simplicable.com/new/globalculture). 